\title{
Assessment of Trophic State of Lakes: A Case of Mansi Ganga Lake in India
}

\section{M.P. Sharma, Arun Kumar and Shalini Rajvanshi}

Abstract: Due to rapid growth of population coupled with urbanization, the water bodies, especially, rivers, lakes, ponds, reservoirs etc are deteriorating due to heavy pollutational stresses resulting in the scarcity of drinking water resources. The present paper attempts to review the work done on the development of TSI for assessment of trophic state of lakes and applicability of most important TSI methods for Indian lakes. The paper also deals with the revival of Mansi Ganga Lake in Mathura, especially, assessment of its trophic state based on the data collected for 2006-09. The results indicated that the lake was oligotrophic during 2006 which has become mesotrophic in the year 2008 showing increase in pollution. After the chemical treatment for the removal of algae, the lake water was drained and results of sampling done in 2009 (pre-monsoon) indicated it to be eutrophic. This calls for its immediate revival and accordingly, the conservation measure are suggested.

Key words: Eutrophication, Trophic State Index (TSI), Total Phosphorus (TP), Secchi depth (SD), Chlorophyll 'a' (Chl'a')

\section{Introduction}

T akes are important feature of the Earth's landscape ـ which are not only the source of precious water, but provide valuable habitats to plants and animals, moderate hydrological cycles, influence microclimate, enhance the aesthetic beauty of the landscape and extend many recreational opportunities to humankind. The lakes are also used for drinking, irrigation, fishing, eco-toursim etc apart from the above advantages.

The different problems of the lake include excessive influx of sediments from the lake catchment, discharge of untreated or partially treated sewage and industrial waste waters/ solid waste, entry of diffused nutrients source from agricultural and forestry, improper management of storm water, overabstraction, over-exploitation oflakeforactivities like recreation, fishing, encroachments, land reclamation etc causing lake water shrinkage, shoreline erosion and impacting the lake hydrology, deteriorating water quality, impacting bio diversity, bringing climate changes etc. There is, therefore, an immediate need to know the pollution status of a lake at given time so that necessary conservation activities may be undertaken to regain/improve the health of water body. This can be done by measuring trophic state index (TSI) to know its trophic state.

The estimation of TSI requires six physical, chemical and biological parameters including total phosphorus (TP), total nitrogen (TN), chemical oxygen demand (COD), Secchi disk depth (SD), chlorophyll-'a' (Chl-a) concentration and phytoplankton biomass (CA) to know the eutrophication state of the lake environment. During 1960-70, a number of researchers have made attempts to quantitatively evaluate the trophic state of lakes using single-variable trophic indices or multi-parametic approaches (Vollenweider 1968 and 1976, Dobson et al 1974, Schindler 1977, Chapra 1980, Ritter 1981, Gregor and Rast 1982, Persson and J ansson 1988, Thornton and Rast 1988, Cobelas et al 1992, and Boers et al 1993). The single-variable trophic indices can be divided into abiotic and biotic aspects. Among the abiotic parameters, plant nutrients (phosphate, nitrate), oxygen demand (BOD, COD) and transparency were usually used to assess lake trophic levels. Rosenberg and Resh (1993) employed the biotic parameters to assess lake trophic conditions given the sensitivity of aquatic organisms, especially algae and macro-invertebrates, to eutrophication processes. Shannon and Brezonik (1972a and b), Carlson (1977) and Cruzado (1987) studied the multidimensional nature of the eutrophication and reported that no single variable can represent status of eutrophication of given water body

The contributions of Carlson (1977), Walker (1979) and Porcella et al (1980) offer a 0-100 scale providing continuous numerical classes of lake trophic states and a rigorous foundation for quantitative studies of the mechanisms behind the eutrophication. The TSI based on several biological, chemical and physical indicators is offered by Carlson TSI. Carlson (1977), Walker (1979) and Porcella et al (1980) along with Aizaki et al (1981), J in et al (1990) and Swanson (1998) provided the most suitable and acceptablemethod for evaluatinglake eutrophication status. As such, no TSI has been developed in India but Carlson's TSI is largely adopted and applied to the Indian lakes.

The present paper reviews the two most important TSI used for assessing the trophic status of lakes, especially, Indian lakes, and have been applied to Mansi Ganga Lake in District Mathura of Uttar Pradesh state based upon the data collected from seven different locations over a period of three years. The results indicate that the status of the lake is gradually shifting from oligotrophic to mesotrophic and to eutrophic state. Conservation measures have also been suggested in this paper.

\section{Literature Review}

Various methods have been employed for the classification of lakes and to indicate their trophic status. The most commonly and widely used method is based 
on productivity, and the frequently used biomass related trophic stateindex is that of Carlson (1977). Further, theU.S. Environmental Protection Agency (EPA) developed indices based on macrophyte cover and DO depletion over the whole lake. The TSI for total nitrogen (TN) was developed by Kratzer and Brezonik (1981) for Florida lakes. Mandaville $(2000,2005)$ studied the trophic state of shallow lakes and ponds using Carlson's Index and used the macrophytes to assess a numerical trophic state index for lakes on a scale of 0 to 100 . Each major division $(10,20,30$, etc.) represents a doubling in algal biomass. The index number can be calculated from any of the several parameters including Secchi disk transparency, chlorophyll and total phosphorus (Carlson 1980).

A modified version of the BonHomme Index was developed for Indiana in 1972 (Johns 1998). Physical, chemical, and biological data collected on each lake were combined into a standardized multi-metric index known as Indiana Trophic State Index (ITSI) to identify the effects of stratification on the water quality. Eutrophic points are assigned to each parameter and summed up to create a final ITSI score ranging from 0 to 75. Lower scores indicate lower levels and lower effects of nutrients on factors related to lake management including water clarity, nutrients available for plant growth and blue green algae dominance and vice- versa. Fu-liu, Shu and Dawson (2001) applied GIS technique to synthesize information from the trophic state parameter for spatial distribution of eutrophication conditions with the help of Carlson's Index. Sandeep (2008) also worked on the TSI in the conservation of lakes using Carlson's Trophic Index and found that TSI is an important aspect of lake survey and is an aspect of water quality and can be used as tool to measure trophic state where biomass is involved. Ludovisi and Poletti (2003) used ecological indicators for the trophic state of lake ecosystems and found that energy and specific energy indices have good negative correlation with phytoplankton biomass and Carlson's Trophic State Index (TSI) and strong positive correlation with respect to water transparency.
From the above literature, it is seen that Carlson's Index has largely been used to assess the trophic status of lakes in almost all the countries including India. As such no reports are available on the development of TSI system for Indian lakes but Carlson's TSI is presently used to assess the status of lakes in India.

\section{Trophic State Index (TSI)}

The trophic status refers to the level of productivity in a lake as measured by phosphorous, algae abundance and depth of light penetration. TSI rates individual lakes, ponds and reservoirs based on theamount of biological productivity occurring in the water. Using the index, one can get a quick idea about the extent of productivity of a lake (Hillsborough 2008). TSI values can be used to rank lakes within a region and between the regions. This ranking enables the water managers to target lakes that may require restoration or conservation activities. An increasing trend in TSI over a period of several years may indicate the degradation of the

Table 1. Review of Different Methods for Determining the TSI of Lakes

\begin{tabular}{|c|c|c|c|}
\hline SN & Method & References & Main features \\
\hline 1 & $\begin{array}{l}\text { Boland principal com- } \\
\text { ponents } \\
\text { TSI }\end{array}$ & Boland 1976 & $\begin{array}{l}\text { - A multivariate TSI using analysis of principal } \\
\text { components. } \\
\text { - Variables used are annual mean for conductiv- } \\
\text { ity. inverse SD. TP. total organic nitrogen, and } \\
\text { algal assay. }\end{array}$ \\
\hline 2 & $\begin{array}{l}\text { Bokmd principal com- } \\
\text { ponents } \\
\text { TSI, (Boland TSI ) }\end{array}$ & Boland 1976 & $\begin{array}{l}\text { - The same as the above except Total Kjeldahl } \\
\text { Nitrogen (TKN) used instead of organic nitrogen } \\
\text { - Mean summer values are used instead of an- } \\
\text { nual values }\end{array}$ \\
\hline 3 & $\begin{array}{l}\text { U.S. EPA Corvallis Envi- } \\
\text { ronmental Research } \\
\text { Laboratory TSI (Corval- } \\
\text { lis TSI) }\end{array}$ & $\begin{array}{l}\text { EPA 1971, } \\
1974 a, b\end{array}$ & $\begin{array}{l}\text { - A multivariate index using a percentile ranking } \\
\text { procedure. } \\
\text { - } 250 \text { lakes sampled in } 1973 \text { were assesd using } \\
\text { the TSI. } \\
\text { - The TSI is equal to the sum of the percentile } \\
\text { ranks for each parameter used (annual mean of } \\
\text { TP, inorganic nitrogen, dissolved orthophospho- } \\
\text { rus, SD, chlor 'a' and minimum DO }\end{array}$ \\
\hline 4 & $\begin{array}{l}\text { Vollenweider phospho- } \\
\text { rus loading mode }\end{array}$ & Vollenweider 1975 & $\begin{array}{l}\text { - Use TP input and output to a lake and predict } \\
\text { mean/ ambient lake TP at equilibrium }\end{array}$ \\
\hline 5 & $\begin{array}{l}\text { Dillon phosphorus } \\
\text { loading model }\end{array}$ & $\begin{array}{l}\text { Dillon 1975, Dillon } \\
\text { and Rigler } 1974\end{array}$ & Not indicated \\
\hline 6 & $\begin{array}{l}\text { Larsen and Mercier } \\
\text { loading model }\end{array}$ & $\begin{array}{l}\text { Larsen and Mer- } \\
\text { cier } 1976\end{array}$ & Not indicated \\
\hline 7 & $\begin{array}{l}\text { Algal assay control } \\
\text { yield (AACY) }\end{array}$ & EPA 1971 & $\begin{array}{l}\text { - Based on primary production potential in a } \\
\text { water sample }\end{array}$ \\
\hline 8 & $\begin{array}{l}\text { Nygaard phytoplankton } \\
\text { myxophycean TSI }\end{array}$ & Nygaard 1941 & Not indicated \\
\hline 9 & $\begin{array}{l}\text { Nygaard phytoplankton } \\
\text { chlorophycean TSI }\end{array}$ & Nygaard 1941 & Not indicated \\
\hline 10 & $\begin{array}{l}\text { Palmer algal genus } \\
\text { organic pollution index }\end{array}$ & Palmer 1969 & $\begin{array}{l}\text { - Based on the available information and findings, } \\
\text { based on the tolerance of organic pollution, the } \\
\text { value of assigned a number, moderately tolerant } \\
\text { form, to } 5 \text { for extremely tolerant and, to } 20 \text { for } \\
\text { algal general }\end{array}$ \\
\hline 11 & $\begin{array}{l}\text { Palmer algal species } \\
\text { organic pollution index }\end{array}$ & Palmer 1969 & $\begin{array}{l}\text { - Similar to Palmer genus OPI except index } \\
\text { numbers range from I to } 6 \text { and species are used }\end{array}$ \\
\hline
\end{tabular}


health of a lake. Table 1 reviews the different types of TSI developed and the corresponding main lake characteristics.

\section{Methods to Determine the TSI}

Numerous method have been developed to measure the trophic state (TS) of lakes. Twenty-nine different methods commonly used were compared with respect to their ability to measure TSI of lakes. Most of the methods have been found more effective in ranking the lakes using the total phosphorus standard compared to chlorophyll 'a' standard (Lambou et al 1983). A number of authors have used different methods in the literature to determine the TSI of lakes (Boland 1976; Dillon 1975; Dillon and Rigler 1974; Larsen and Mercier 1976; Naumann 1931; Nygaard 1949; Palmer 1969; Pielou 1966; Shannon and Brezonik 1972; EPA 1971, 1974a,b and 1975; and Vollenweider 1975).

Out of these methods, the following two most important and popular TSI method selected for the present study are given below.

\section{Carlson's Trophic Status Index and water quality}

Carlson [15] developed TSI and water quality index for lakes and rivers respectively as given in Table 2 and the Indiana TSI is given in Table 3.

The following equations can be used to compute the Carlson's TSI .

TSI - P $=14.42 * \operatorname{Ln}[\mathrm{TP}]+4.15$ (in ug/ L)--------- (i)

TSI - C $=30.6+9.81$ Ln [Chlor-a] (in ug/ L)------- (ii)

TSI - S = 60 - 14.41* Ln [SD] (in meters)---------- (iii)

Average TSI $=[$ TSI (P) + TSI (CHL 'a') + TSI (SD) $] / 3-$ (iv)

where TP is total phosphorus, chlor ' $a$ ' is chlorophyll 'a', SD the sechhi depth

Trophic status index and water quality of Indiana

The Indiana trophic state index has a eutrophy points represented by total phosphorus, chlorophyll, nitrogen, DO and sechhi depth (J ohns 1998). The TSI scores and trophic state of Indiana TSI is given in Table 3. To add the Eutrophy points of TP, TN,SD, DO and feacal, the status of lake can be computed on the basis of TSI Score and the details provided in (Johns 1998).

\section{Revival of Mansi Ganga Lake - A case study}

About Mansi Ganga lake (MGL)

Manasi Ganga Kunda is traditionally the starting and ending point of the circumambulation of Govardhana Hill. In Mathura-mahatmya, the tradition is to take bath in Manasi Ganga and then visit Harideva before the beginning of Govardhana parikrama. This kunda is considered a million times more potent than Ganges River as by taking bath in Ganges River, one can get "Krishna prema," love
Table 2, Carlson's Trophic State Index

\begin{tabular}{|c|l|l|}
\hline TSI & \multicolumn{1}{|c|}{ Status } & \multicolumn{1}{c|}{ Status of lakes } \\
\hline $30-40$ & Oligotrophy & $\begin{array}{l}\text { Classical Oligotrophy: Clear water, oxygen } \\
\text { throughout the year in the hypolimnion, salmo- } \\
\text { nid fisheries in deep lakes. }\end{array}$ \\
\hline $40-50$ & Mesotrophy & $\begin{array}{l}\text { Deeper lakes still exhibit classical oligotrophy, } \\
\text { but some shallower lakes become anoxic in the } \\
\text { hypolimnion during the summer. }\end{array}$ \\
\hline $50-60$ & Eutrophy & $\begin{array}{l}\text { Water moderately clear, but increasing prob- } \\
\text { ability of anoxia in hypolimnion during summer }\end{array}$ \\
\hline $70-70$ & Eutrophy & $\begin{array}{l}\text { Lower boundary of classical eutrophy: De- } \\
\text { creased transparency, anoxic hypolimnia during } \\
\text { the summer, macrophyte problems evident, } \\
\text { warm-water fisheries only. }\end{array}$ \\
\hline$>80$ & $\begin{array}{l}\text { Dominance of blue-green algae, algal scums } \\
\text { probable, extensive macrophyte problems. }\end{array}$ \\
\hline phy & Hyper eutro- & $\begin{array}{l}\text { Heavy algal blooms possible throughout the } \\
\text { summer, dense macrophyte beds, but limited } \\
\text { light penetration.(Often would be classified as } \\
\text { hypereutrophic) }\end{array}$ \\
\hline $\begin{array}{l}\text { Algal scums, summer fish kills, few macro- } \\
\text { phytes, dominance of rough fish etc. }\end{array}$ \\
\hline 50
\end{tabular}

Table 3. Indiana Trophic State Index (ITSI)

\begin{tabular}{|c|c|}
\hline Indiana TSI Scores & Trophic Class \\
\hline $0-15$ & Oligotrophic \\
\hline $16-31$ & Mesotrophic \\
\hline $32-46$ & Eutrophic \\
\hline $47-75$ & Hypereutrophic \\
\hline
\end{tabular}

of Krishna. Manasi Ganga is considered to be the neck of Govardhana. It is the believed that both Radharani and Krishna would have boated in this lake. Figure 1is the photo of Mansi Ganga Lake at Goverdhan (Mathura,UP). A Google map of the lake shown in Figure 2 also indicate the sampling locations for water samplings.

There are several important places on the banks of Manasi Ganga or nearby like Harideva temple, Manasi Devi temple and Brahma Kunda. On the other side of Manasi Ganga, other places in the same area are Chakra Tirtha, Chakaleswara Mahadeva Temple and Sanatana Gosvami's bhajana kutir. The Mukharavinda temple is close to the Govardhana parikrama road on the bank of Manasi Ganga. The Harideva temp le and the Manasi Devi temple are usually the first places to be visited when doing Govardhana parikrama (a religious ritual). Chakaleswara Mahadeva temple and Sanatana Gosvami's Bhajana Kutir are usually visited after going half way around the hill. The Mukharavinda temple is usually visited after finishing the Govardhana parikrama.

\section{Geographic features of the lake}

The latitude of Mansi Ganga Lake is $27^{\circ} 29^{\prime} 55.91^{\prime \prime}$ N., the longitude is $77^{\circ} 27^{\prime} 49.13^{\prime \prime} \mathrm{E}$., and the altitude is about $185 \mathrm{~m}$ above MSL. The catchment area is about 150 ha with lake area 


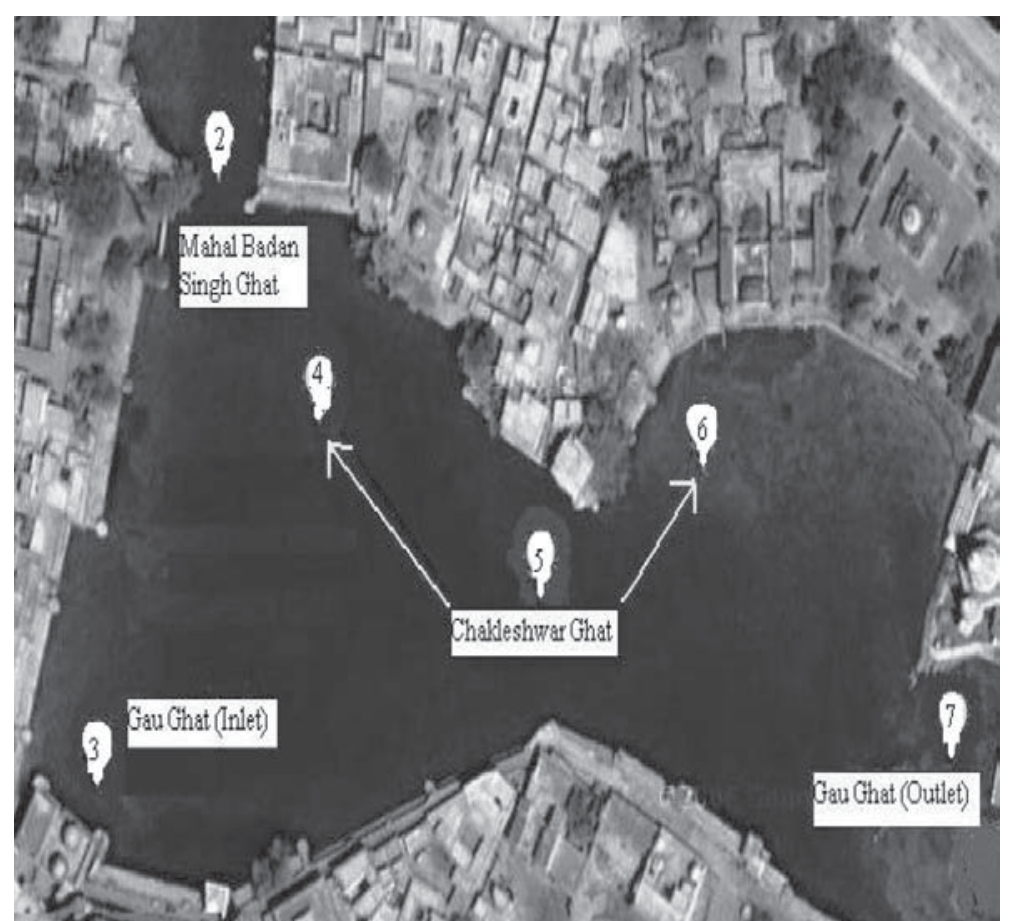

Figure 2. Google Map of Mansi Ganga Lake, Govardhan

of 3.74 ha and depth of about $9.3 \mathrm{~m}$. The water storage capacity is about 0.247 million $\mathrm{m} 3$ with a parimeter of $1700 \mathrm{~m}$. The lake receives water through natural nallah (stream) from northern side and through ground filtration. The average annual rainfall in the catchment is about $593 \mathrm{~mm}$.

\section{Methods and materials}

The samples were collected for the analysis of physic, chemical and biological parameters. Seven sampling locations are shown in Figure 2. The analysis of SD, TN, TP, chlorophyll 'a' and other parameters were performed as per IS and APHA methods (Clesceri 1988). The TSI was calculated by standard equations given above. The TSI based on Carlson's and Indiana method is given in Table 4. Tables 5, 6, 7 and 8 give the data of sampling done during 2006-09 at different times alongwith average TSI of lake based on Carlson's Index. The average values of TSI of Tables 5, 6, 7 and 8 were computed using Carlson's equation to get the TSI of lake. A geographical comparison on the Carlson and Indiana TSI is shown in Figures 3 and 4 and the results are reported in Table 9.

\section{Results and discussions}

Thelakeisgettingpolluted overtime. Thelakewasinitially oligotrophic which has gradually changed to mesotrophic perhaps due to the increased anthropogenic activities in the catchment. The lake becomes slightly oligotrophic during II sampling and finally becomes eutrophic during pre-monsoon 2009 sampling due to increased addition of pollutant/contaminants and draining of lake water for conservation purposes. The results indicate that both TSI can be applied to Indian lakes as both gave the same TSI of MGL. It may be concluded that both the systems can be very well used to assess the TSI of a given water body. Once

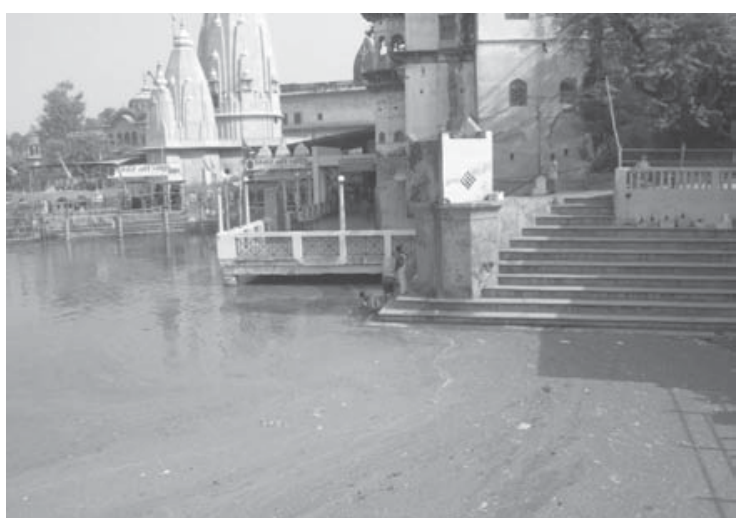

Figure 1. Photo of MGL, Govardhan (Mathura)

the TSI and sources of pollution are qualitatively and quantitatively assessed, the conservation techniques to be applied can be planned and implemented.

\section{Restoration and Revival of Lakes}

Eutrophication is one of the most serious problems affecting the quality of water in multi-reservoir systems. The increase in nutrients leads to greater productivity of the aquatic plants that may lead to excessiveincrease in algal biomass or other primary producers such as macrophytes. Excessive algal biomass can seriously affect the water quality, especially, if it creates anaerobic conditions. Therefore, even when using a simplified approach in a mathematical optimization tool, there is a requirement to include water quality indices associated with the trophic state of reservoirs (Carlson 1977).

Asstated above, eutrophication of alakesystemisgradual progression from one life stage to the another based on the changes in the degree of nutrient input or productivity. The cultural eutrophication can significantly alter the rate of natural process and shorten the life expectancy of the affected water body. Recently, there has been significant efforts being made in India to protect, rehabilitate and restore lakes and impoundments contributing to the country's water resources. Two types of conservation measures are adopted: Control of pollution at source and inlake treatment and control measures. The former concerns with the removal and control of point sources, diversion of nutrients and control of non-print sources while the later deals, with the treatment and control measures like dredging, nutrient inactivation/precipitation, dilution and dispersion, artificial destratification and hypolimmetic aeration, sediment exposure and desiccation, harvesting, chemical/biological control of nuisance organisms, etc.

Table 4. TSI Based on Carlson's and Indiana Method

\begin{tabular}{|c|l|c|c|}
\hline \multirow{2}{*}{ S. No. } & \multirow{2}{*}{ Trophic State } & \multicolumn{2}{|c|}{ Indices Range } \\
\cline { 3 - 4 } & & Carlson's TSI Range & Indiana TSI Range \\
\hline 1 & Oligotrophic & $10-30$ & $0-15$ \\
\hline 2 & Mesotrophic & $31-50$ & $16-31$ \\
\hline 3 & Eutrophic & $51-70$ & $32-46$ \\
\hline 4 & $\begin{array}{l}\text { Hyper-eutro- } \\
\text { phic }\end{array}$ & $71-90,>90$ & $47-75$ \\
\hline
\end{tabular}


Table 5. Analysis of Water Samples of MGL and its TSI (U. P. J al Nigam, Mathura)

\begin{tabular}{|c|c|c|c|c|c|c|c|c|}
\hline \multirow[t]{2}{*}{ Sampling points } & \multicolumn{2}{|c|}{$\begin{array}{c}\text { Sachhi Disc } \\
\text { Transparency } \\
\text { (m) }\end{array}$} & \multicolumn{2}{|c|}{$\begin{array}{c}\text { Total } \\
\text { Nitrogen } \\
(\mathrm{mg} / \mathrm{l}) \\
\end{array}$} & \multicolumn{2}{|c|}{$\begin{array}{c}\text { Total } \\
\text { Phosphorus } \\
\text { (mg / I) }\end{array}$} & \multicolumn{2}{|c|}{$\begin{array}{l}\text { Chlorophyll a } \\
\qquad(\mu \mathrm{g} / \mathrm{l})\end{array}$} \\
\hline & SD & TSI & $\mathrm{TN}$ & TSI & TP & TSI & Chl ' a' & TSI \\
\hline Gaun Ghat & - & - & 1.15 & 9.62 & 1.10 & 5.52 & 2.12 & 37.97 \\
\hline Mahal Badan Singh Ghat & - & - & 0.35 & 72.31 & 0.91 & 2.79 & 2.58 & 39.89 \\
\hline In front of Nagar Panchayat & - & - & 1.10 & 6.56 & 0.86 & 1.97 & 6.4 & 48.81 \\
\hline Chakleshwar Ghat & 0.099 & 0.921 & 0.65 & 29.67 & 0.94 & 3.25 & 3.68 & 43.38 \\
\hline Chakleshwar Ghat & - & - & $1.52 ।$ & 28.24 & 0.836 & 1.46 & 6.2 & 48.49 \\
\hline Chakleshwar Ghat & 0.123 & 4.80 & 0.70 & 24.56 & 0.72 & 8.88 & 5.68 & 47.63 \\
\hline Gau Ghat outlet from Third Burji & 0.107 & 73.37 & 1.10 & 6.56 & 0.87 & 6.15 & 4.28 & 44.86 \\
\hline Average & & 26.36 & & 25.44 & & 4.28 & & 44.43 \\
\hline
\end{tabular}

TSI = Oligotrophy $(20-30)$

Table 6. Analysis of Water Samples of MGL and TSI (Based on 1st Sampling, December 2007)

\begin{tabular}{|l|l|l|l|l|l|l|l|l|}
\hline \multirow{2}{*}{ Sampling Points } & \multicolumn{2}{|c|}{$\begin{array}{c}\text { Sachhi Disc } \\
\text { Transparency } \\
(\mathrm{m})\end{array}$} & \multicolumn{2}{|c|}{$\begin{array}{c}\text { Total } \\
\text { Nitrogen } \\
(\mathrm{mg} / \mathrm{I})\end{array}$} & \multicolumn{2}{c|}{$\begin{array}{c}\text { Total } \\
\text { Phosphorus } \\
(\mathrm{mg} / \mathrm{I})\end{array}$} & \multicolumn{2}{c|}{$\begin{array}{c}\text { Chlorophyll a } \\
(\mu \mathrm{I} / \mathrm{l})\end{array}$} \\
\cline { 2 - 10 } & SD & TSI & TN & TSI & TP & TSI & Chl 'a' & TSI \\
\hline Gaun Ghat & 0.22 & 69.02 & 3.9 & 44.93 & 5.84 & 29.59 & 4.42 & 45.17 \\
\hline Mahal Badan Singh Ghat & 0.24 & 65.06 & 9.8 & 30.74 & 5.20 & 27.92 & 5.04 & 46.46 \\
\hline In front of Nagar Panchayat & 0.20 & 73.37 & 7.4 & 44.93 & 3.96 & 23.99 & 4.01 & 44.22 \\
\hline Chakleshwar Ghat & 0.21 & 71.14 & 6.1 & 60.30 & 5.82 & 29.54 & 5.43 & 47.19 \\
\hline Chakleshwar Ghat & 0.21 & 92.22 & 16.8 & 35.73 & 7.56 & 33.31 & 3.50 & 42.88 \\
\hline Chakleshwar Ghat & 0.21 & 71.14 & 1.1 & 83.47 & 12.16 & 40.17 & 2.81 & 40.73 \\
\hline Gau Ghat outlet from Third Burji & 0.19 & 75.17 & 7.8 & 98.84 & 20.70 & 47.84 & 15.49 & 57.48 \\
\hline Average & & 73.87 & & 56.99 & & 33.19 & & 46.37 \\
\hline
\end{tabular}

$\mathrm{TSI}=$ Mesotrophy $(40-50)$.

Table 7. Analysis of Water Samples of MGL and TSI (2nd Sampling, Pre-Monsoon, February 2009)

\begin{tabular}{|l|l|l|l|l|l|l|l|l|}
\hline \multirow{2}{*}{ Sampling Points } & \multicolumn{2}{|c|}{$\begin{array}{c}\text { Sachhi Disc Trans- } \\
\text { parency } \\
(\mathrm{m})\end{array}$} & \multicolumn{2}{|c|}{$\begin{array}{c}\text { Total Nitrogen } \\
(\mathrm{mg} / \mathrm{I})\end{array}$} & \multicolumn{2}{c|}{$\begin{array}{c}\text { Total Phosphorus } \\
(\mathrm{mg} / \mathrm{I})\end{array}$} & \multicolumn{2}{c|}{$\begin{array}{c}\text { Chlorophyll a } \\
(\mu \mathrm{g} / \mathrm{I})\end{array}$} \\
\cline { 2 - 10 } & SD & TSI & TN & TSI & TP & TSI & CHL a & TSI \\
\hline Gaun Ghat & 0.20 & 72.94 & 33.48 & 32.37 & 0.32 & 12.28 & 4.42 & 45.17 \\
\hline Mahal Badan Singh Ghat & 0.23 & 67.00 & 70.4 & 23.17 & 0.64 & 2.285 & 5.04 & 46.46 \\
\hline In Front of Nagar Panchayat & $0.26 \mathrm{c}$ & 61.41 & 31.31 & 54.30 & 0.46 & 7.04 & 4.01 & 44.22 \\
\hline Chakleshwar Ghat & 0.26 & 61.41 & 39.68 & 27.92 & 0.54 & 4.735 & 5.43 & 47.19 \\
\hline Chakleshwar Ghat & 0.25 & 63.20 & 39.83 & 44.21 & 0.84 & 1.635 & 3.50 & 42.88 \\
\hline Chakleshwar Ghat & 0.17 & 80.78 & 40.31 & 51.10 & 1.2 & 6.779 & 2.81 & 40.73 \\
\hline $\begin{array}{l}\text { Gau Ghat outlet from Third } \\
\text { Burji }\end{array}$ & 0.27 & 59.69 & 28.43 & 23.17 & 0.66 & 1.84 & 15.49 & 57.48 \\
\hline Average & & 66.59 & & 36.60 & & 5.22 & & 46.37 \\
\hline
\end{tabular}

TSI = slightly oligotrophic (30-40)

Depending upon the eutrophication state and sources of pollution, one or more techniques alone in combinations can be employed for lake restoration.

In MGL, the conservation measures like desilting, chemical treatment followed by removal of water, collection and treatment of sewage through STPs, installation of aeration system etc have been planned and are being implemented to revive the lake.

\section{Conclusions}

In view of growing pollutional stresses in lakes, the TSI of a lake can be assessed using Carlson's and Indiana TSI methods. These most important have been applied on MGL to asses its trophic state. The results of sampling at seven locations during 2006-09 indicated that the lake has approached to eutrophic state and conservation measures like control of point sources and in lakes treatment methods are being implemented to revive the lake. 
Table 8. Analysis of Water Samples of MGL and TSI (3rd Sampling, Pre-Monsoon, May 2009)

\begin{tabular}{|l|l|l|l|l|l|l|l|l|}
\hline \multirow{2}{*}{ Sampling Points } & \multicolumn{2}{|c|}{$\begin{array}{c}\text { Sachhi Disc } \\
\text { Transparency } \\
(\mathrm{m})\end{array}$} & \multicolumn{2}{|c|}{$\begin{array}{c}\text { Total } \\
\text { Nitrogen } \\
(\mathrm{mg} / \mathrm{I})\end{array}$} & \multicolumn{2}{c|}{$\begin{array}{c}\text { Total } \\
\text { Phosphorus } \\
(\mathrm{mg} / \mathrm{I})\end{array}$} & \multicolumn{3}{c|}{$\begin{array}{c}\text { Chlorophyll a } \\
(\mu \mathrm{\mu g} / \mathrm{I})\end{array}$} \\
\cline { 2 - 11 } & SD & TSI & TN & TSI & TP & TSI & CHL a & TSI \\
\hline Gaun Ghat & 0.08 & 114 & NA & - & 1.72 & 11.95 & 8.19 & 51.22 \\
\hline Mahal Badan Singh Ghat & 0.2 & 72.94 & - & - & 0.27 & 14.70 & 14.02 & 56.50 \\
\hline Chakleshwar Ghat & 0.1 & 104.9 & - & - & 0.55 & 4.45 & 17.4 & 58.62 \\
\hline Chakleshwar Ghat & 0.07 & 120.2 & - & - & 0.17 & 21.36 & 19.88 & 59.92 \\
\hline $\begin{array}{l}\text { Gau Ghat outlet from Third } \\
\text { Burji }\end{array}$ & 0.13 & 93.65 & - & - & 0.17 & 21.36 & 14.60 & 56.90 \\
\hline Average & & 100 & - & - & & 14.76 & & 56.63 \\
\hline
\end{tabular}

$\mathrm{TSI}=$ Eutrophy $(60-70)$

Table 9. Comparison of TSI of MGL

\begin{tabular}{|l|c|c|c|c|c|c|c|}
\hline & TN & TP & TSD & TCA & DO & Carlson's TSI & Indiana TSI \\
\hline $\begin{array}{l}\text { U.P. Jal } \\
\text { Nigam }\end{array}$ & $0.37-1.52$ & $0.72-1.1$ & $2.12-6.4$ & $0.09-0.10$ & - & $\begin{array}{c}\text { Oligotrophy } \\
(20-30)\end{array}$ & $\begin{array}{c}\text { Oligotrophy } \\
(0-15)\end{array}$ \\
\hline $1^{\text {st }}$ sampling & $1.1-16.8$ & $3.96-20.70$ & $0.19-0.24$ & $2.81-15.49$ & $4.0-7.5$ & $\begin{array}{c}\text { Mesotrophy } \\
(40-50)\end{array}$ & $\begin{array}{c}\text { Mesotrophy } \\
(16-31)\end{array}$ \\
\hline $\begin{array}{l}2^{\text {nd }} \text { sam- } \\
\text { pling }\end{array}$ & $28.43-70.4$ & $0.32-1.2$ & $0.17-0.27$ & $2.81-15.4$ & - & $\begin{array}{c}\text { Slightly } \\
\text { Oligotrophy } \\
(30-40)\end{array}$ & $\begin{array}{c}\text { Slightly } \\
\text { Oligotrophy } \\
(0-15)\end{array}$ \\
\hline $\begin{array}{l}3^{\text {rd }} \text { sam- } \\
\text { pling }\end{array}$ & - & $0.17-1.72$ & $0.05-0.1$ & $8.19-17.4$ & - & $\begin{array}{c}\text { Eutrophy } \\
(50-70)\end{array}$ & $\begin{array}{c}\text { Eutrophy } \\
(32-46)\end{array}$ \\
\hline
\end{tabular}

TSI

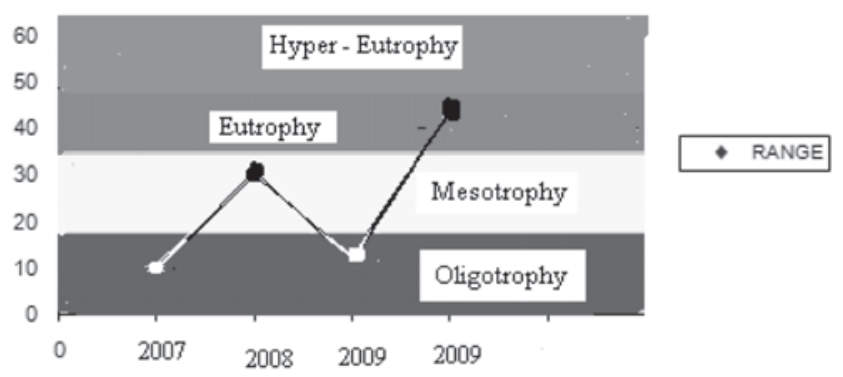

Figure 3. TSI of MGL Using Carlson's Index

Dr M.P.Sharma has been working as Associate Professor at Alternate Hydro Energy Centre, Indian Institute of Technology, Roorkee (India), since the last 25 years. His areas of research are renewable energy with special reference to modeling of IRES, hybrid energy systems, modelling of induction generators, EIA of renewable energy projects, energy conservation, conservation of environment, conservation of water bodies, water quality assessment, and biodiesel production and utilization.

Corresponding address: mpshafah@iitr.ernet.in or mahendrapal_sharma@gmail.com
TSI

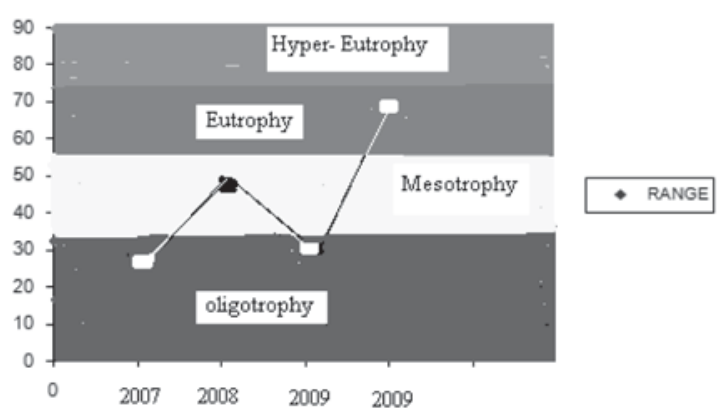

Figure 4. TSI of MGL Using Indiana Index

Dr Arun Kumar, Chief Scientific Officer and Head, Alternate Hydro Energy Centre, I.I.T. Roorkee, India, He has been working since the last 25 years in the area of small hydro power development and conservation and management of rivers and lakes. His areas of research is the development of civil structures for SHP and Conservation of Water Resources through the use of suitabletechnologies in river and lakes.

Corresponding address: akumafah@iit.ernet.in

Ms. Shalini Rajvanshi is MSc in Organic Chemistry and is working as Project Associatein a consultancy project on the revival of Mansi Ganga Lake.

Corresponding address: rajvanshiroorkee@gmail.com 


\section{References}

Aizaki, M., T. Iwakuma and N. Takamura, 1981, 'Application of modified Carlson's trophic state index to Japanese lakes and its relationship to other parameters related to trophic state', Res. Rep. Natl. Inst. Environ. Stud. v.23, pp.13-31.

Boers, C.M., T.E. Cappenberg and W. Van Raaphorst, 1993, 'Phosphorus in sediments', Hydrobiologia v.253, pp.17-376.

Boland, D.H.P., 1976, Trophic Classification of Lakes Using Landsat-1 (ERTS-I) Multispectral Scanner Data, EPA-600376-037, 244, Corvallis, Oregon: U.S. Environmental Protection Agency.

Carlson, R.E. 1977, 'A trophic state index for lakes', Limnology and Oceanography v.22, n.2, pp.361-369.

Carlson, R.E., 1980, 'More complications in the chlorophyllsecchi disk relationship', J ournal of Limnology and Oceanography v.25, pp.378-382.

Chapra, S.C., 1980, 'Application of the phosphorus loading concept to the Great Lakes', pp.135-152, in C. Loehr, C.S. Martin and W. Rast, eds., Phosphorus Management Strategies for Lakes, Ann Arbor, MI: Ann Arbor Science Publishers.

Clesceri, S. Lenore, E. Arnold Greenberg and Andrew D. Eaton, 1988, Standard Methods for the Examination of Water and Wastewater, Washington DC: American Public Health Association.

Cobelas, Alvarez, P. Munoz Ruiz, A. Rubio Olmo and N. Prat i Fornells, 1992, 'Current state of eutrophication in spanish inland waters', Eur. Water Pollut. Cont. v.25, pp.27-32.

Cruzado, A., 1987, Eutrophication in the pelagic environment and its assessment. Pp.57-66 in Proceedings of Eutrophication in the Mediterranean Sea: Receiving Capacity and Monitoring of Long Term Effects, UNESCO Reports in Marine Science No.49.

Dillon, P.J. and F.H. Rigler, 1974, 'The phosphorus chlorophyll relationship in lakes', Limnology and Oceanography v.19, pp.767773.

Dillon, P.J., 1975, 'The phosphorus budget of Cameron Lake, Ontario: The importance of flushing rate to the degree of eutrophy of lakes', Limnology and Oceanogrraphy v.20, pp.28-39.

Dobson, H.F.H., M. Gilbertson and P.G. Sly, 1974, 'A summary and comparison of nutrients and related water quality in Lake Erie, Ontario, Huron and Superior', J . Fish. Res. Bd. Can. v31, pp.731-738.

EPA, 1971, Algal Assay ProcedureBottleTest, Corvallis, Oregon: National Eutrophication Research Program, U.S. Environmental Protection Agency.

EPA, 1974a, An Approach to a Relative Trophic Index System for Classifying Lakes and Reservoirs, National Eutrophication Survey Working Paper No.24, p.45, Corvallis, Oregon: U.S. Environmental Protection Agency.

EPA, 1974b, National Eutrophication Survey Methods for Lakes Sampled in 1972, National Eutrophication Survey Working Paper No.1, p.40, Las Vegas, Nevada and Corvallis, Oregon: National Environmental Research Centers, U.S. Environmental Protection Agency.

EPA, 1975, National Eutrophication Survey Methods, 19731976, National Eutrophication Survey Working Paper No.175, p.19,
Las Vegas, Nevada and Corvallis, Oregon: National Environmental Research Laboratories, U.S. Environmental Protection Agency.

Fu Liu Xu, Shu Tao, R.W. Dawson and Beng Gang Li, 2001, 'A GIS based method of lake eutrophication assessment', Ecological Modelling v.144, pp.231-244.

Gregor, D.J. and W. Rast, 1982, 'Simple trophic state classification of the Canadian nearshore waters of the Great Lakes, Water Resources Bulletin v.18, n.4, pp.565-573.

Hillsborough, 2008, 'Trophic State Index(TSI)', in Hillsborough Community Atlas, City of Tampa, Florida: Hillsborough County; URL: www.hillsborough.community atlas.usf.edu.

Jin X., Tu Q.Liu, Z Zhangand X. Zhu, 1990, Eutrophication of Lakes in China, Beijing" China Environmental Sciences Press.

Kothandaraman, V., 1981, 'An overview of in-lake treatment technologies for water quality management' Proceedings of the Round Table on Reclaiming and Managing Lakes in Illinois, Urbana-Champaign, October 10-11, 1980, Champaign, Illinois: Illinois Institute of Natural Resources.

Kratzer, C.R., and P.L. Brezonik, 1981, 'A Carlson-type trophic state index for nitrogen in Florida lakes', Water Resources Bulletin, v.17, n.4, pp.713-715, 1057-1060.

Lambou, V.W., W.D. Taylor, S.C. Hern and L.R. Williams, 1983, 'Comparisons of Trophic State Measurement', Water Resources v.17, pp.1619-1626.

Larsen, D.P. and H.T. Mercier, 1976, 'Phosphorus retention capacity of lakes', J . Fish. Res. Bd Can v.33, pp.1742-1750.

Ludovisi, Alessandro and Poletti, Antonio, 2003, 'Use of thermodynamics indices as ecological indicators, the development state of lake ecosystem', Ecological Modeling v.159, pp.223-238.

Mandaville, S.M., 2000, Limnology-Eutrophication and Chemistry, Carrying Capacities, Loadings, Benthic Ecology, and Comparative Data, Halifax: Soil and Water Conservation Society of Metro Halifax (Synopses 1,2,3, 13 and 14: 210).

Mandaville, S.M., 2005, Trophic State and Data Evalution Methodology, Dartmouth, NS, Canada: EnvironmentalManagement Services; URL:lakes.chebucto.org(DATA)/ PARAMETERS/TP/ CCMC.pdf.

Naumann, E., 1931, Limnologische Terminologie, Berlin and Vienna: Urban and Schwarzenburg.

Nygaard, G., 1949, 'Hydrobiological studies in some Danish ponds and lakes', Biological Sciences v.7,p.293.

Palmer, C.M., 1969, 'A composite rating of algae tolerating organic pollution', J ournal of Phycology v.5, pp.78-82.

Persson, G. and M. Jansson, 1988, 'Phosphorus in freshwater ecosystems', Hydrobiologia v.170, pp.1-340.

Pielou, E.C., 1966, ;The measurement of diversity in different types of biological collections', J ournal of Theoretical Biology v.13, pp.131-144.

Porcella, D.B., S.A. Peterson and D.P. Larsen, 1980, 'Index to evaluate lake restoration, J ournal of Environmental Engineering, Div. ASCE 106 EE6, pp.1151-1169.

Ritter, W.F., 1981, Survey and Classification of Delaware's Public Lakes,Philadelphia: U.S. Environmental Protection Agency.

Rosenberg, D.M. and V.H. Resh, eds., 1993, Freshwater 
Biomonitoring and Benthic Macroinvertebrates, London and New York: Chapman and Hall.

Sandeep, B.M., S. Srikantaswamiy and Shankar P. Hosmani, 2008, 'The study of phytoplankton dynamics in two lakes of Mysore, Karnataka state', Journal of Nature Environment and Pollution Technology v.7, n.4, pp.300-306.

Schindler, D.W., 1977, Evolution of phosphorus limitation in lakes, Science v.195, pp.260-262.

Shannon E.E. and Brezonik P.L. 1972a, 'Eutrophication analysis: a multivariate approach', J. San. Eng. Div. ASCE v.981, pp.37-57.

Shannon, E.E. and P.L. Brezonik, 1972b, 'Eutrophication analysis: a multivariate approach', J ournal of Sanitary Engineering Division, ASCE, v.98, pp.37-58.

Shannon, E.E. and P.L. Brezonik, 1972b, Eutrophication: Cause-Effect Relationships, Gainesville: Florida University, Department of Environmental Engineering.

Swanson, E.R. 1998, 'Trophic state index revisited', Lake Line v.18, n.4, pp.18-20.

Thornton, J.A. and W. Rast, 1988, Preliminary observations on comparative limnology of north and south semi-arid manmade lakes and possible implications for eutrophication assessment', a paper presented at the 8th Annual International Symposium on Lake and Watershed Management.

Vollenweider, R.A., 1968, 'The scientific basis of lake eutrophication with particular reference to phosphorus and nitrogen as eutrophication factors', Technical Report DAS/DSI 68.27, Paris: OECD.

Vollenweider, R.A., 1975, Input-output models with special reference to the phosphorus loading concept in limnology. Schweiz, J . Hvdrol. V.37, PP.58-83.

Vollenweider, R.A., 1976, 'Advances in defining critical loading levels for phosphorus in lake eutrophication,' Memorie della Societa Entomologica Italiana v.33, pp.53-83.

Walker, W.W., 1979, 'Use of hypolimnetic oxygen depletion rate as a trophic state index for lakes', Water Research v.15, n.6, pp.1463-1470.

Johns, William, 1998, Indiana Trophic State Index, Indianapolis, Indiana: Lakes Water Quality Assessment Program, Indiana Department of Environmental Management. •

\section{READER'S REVIEW}

\section{Expand Coverage and Congrats}

Hearty congratulations to "Hydro Nepal" on winning coveted International 'India Power Award 2009' for excellence. Every issue of Hydro Nepal is at par with other international journals of similar nature publications. As a regular reader of your journal I should admit that your coverage of hydropower overshadows other sectors of water like water supply, irrigation, wetland and environmental issues. Hope your future issues will improve on these fields. Once again congrats for your brilliant performance.

\section{- Mathura Dangol \\ Superintending Engineer, Ministry of Irrigation, Govt. of Nepal}

\section{Include contributions from Academia}

I have read through all of the issues of your Journal on Water, Energy and Environment published to date and keep wishing that the next issue comes sooner than later. The papers and other material published in the Journal are mostly well researched, written and edited. I sincerely appreciate your efforts in bringing forth such a high-quality publication. I have one observation to make. I have seen little contribution from the academia, in particular from the engineering faculty and students at our Universities. I, therefore, urge you to get in touch with appropriate faculty members at the engineering colleges. Those faculty members may be willing to contribute and may even want their students to send in papers. Some initial initiative will be required from your side in this regard since this J ournal is still in a nascent stage. Eventually, when Hydro Nepal evolves into a well-known publication, people will have to wait for their turn to have their papers published in it. I have one more suggestion - you might want to publish special issues every year or twice a year with special themes. One very important and pressing theme in today's context would be 'Climate Change and its Impact on Nepal's Water and Energy Resources and Himalayan Ecosystems.' I am sure you will consider my suggestion in good spirit. I wish you success in your future endeavors.

- Sanjay Sharma Superintending Engineer, Dept. of Electricity Development, Govt. of Nepal

\section{Wishing you all the best}

I am pleased to havean opportunity to read articles in the HYDRO Nepal J ournal. I found it is well structured and of international standard and useful to all whom are interested to the Water, Energy and Environmental field. This is right time to do some thing to the country for energy sector and HYDRO Nepal has to push to all. I would like to Congratulate to the HYDRO Nepal team that the J ournal has received an International award from India Power 2009. Wishing you all the best and success in future.

- Li Zhong, Chief Engineer

Hunan Chendian International Development ShareHolding Co. Ltd., P.R. China, email: LWLZ1110@126.com

Editor's Note: We will try to implement your good suggestions. 